\title{
RECENT STATISTICAL TRENDS IN AUSTRALIAN LEGAL EDUCATION
}

\author{
DAVID WEISBROT*
}

\section{THE GROWTH IN NUMBERS}

Law Schools The central message of the Pearce Report on Australian Law Schools ${ }^{1}$ was that legal education in Australia is being run on the cheap, and this is a Bad Thing. The moral for Vice Chancellors, University Councils and Governments, however, is that legal education in Australia can be run on the cheap, and this is an Absolutely Splendid Thing.

In 1960, there were six university law schools in Australia one in each state capital. By the mid-1970s the number had doubled, with second law schools established in Victoria and Queensland, three new law schools in New South Wales, and another established at the Australian National University in Canberra. One of the law schools in each of Queensland and New South Wales was established in an Institute of Technology, foreshadowing the end of the binary divide in higher education.

By the mid-1990s, the number of law schools will double again. New law schools have already been established, or are about to be established, at seven more public universities: Murdoch University, Wollongong University, Newcastle University, the University of the Northern Territory, Flinders University, Griffith University and James Cook University. La Trobe University's well-known legal studies department is also set to begin offering LLB degrees for the first time, in addition to the BA in Legal Studies.

Similarly, the legal studies group within the Business and Commerce Faculty of the University of New England, in Armidale, 
NSW, is currently taking active steps towards the creation of a separate law school. The University also has a branch in Coffs Harbour and is one of the leaders in distance education, so that there are arguments in favour of this move despite the already crowded field. The conversion of the legal studies department into a law school at the University of Canberra is also strongly rumoured. Further, there is also likely to be pressure soon to establish a law school at the University of Western Sydney, which already houses some legal studies departments at its separate campuses and is located in a heavily populated region which is poorly served by professional faculties (and services).

The Victorian Post Secondary Education Commission (VPSEC) recently not only approved the LLB program for La Trobe but also a new law course to be offered jointly by the Victorian University of Technology and Deakin University. The VPSEC found that there was a high level of unmet demand for places in Law in Victoria, that there was a particular need for country Victoria to be served by distance education in law, and that there currently are significantly fewer opportunities for legal education in Victoria than in New South Wales and Queensland. ${ }^{2}$

Private law schools also have emerged in the last several years and will continue to do so. The law school at Bond University is clearly the major success story thus far within Australia's first private university. The new Catholic University of Notre Dame in Perth has plans to establish a law school, and it is not surprising that the foundation Vice Chancellor is a former Dean of the wellregarded Notre Dame Law School in the United States ${ }^{3}$ The Australian Catholic University in New South Wales has also announced its intention to have Law among its early faculties. Hastings International University, which will set up operations on the North Coast of New South Wales, has foreshadowed plans to offer a degree in jurisprudence, under a franchise agreement with Bond University. ${ }^{4}$

The earlier expansion of the university system in Australia, including the university law schools, was fuelled by the express recommendations of the 1964 Martin Report on the Future of Tertiary Education in Australia ${ }^{5}$ followed by massive increases in federal funding by the Menzies and, especially, Whitlam Governments. Ironically, the second wave of expansion of legal education in the 1990s comes at a time when the Pearce Report has 
discouraged such a direction, the federal minister for higher education has assigned Law a very low priority, and government funding for higher education generally is grossly inadequate even for existing programs.

Nevertheless, it appears that there may be a dozen university law schools in New South Wales and the ACT by the mid-1990s (not counting the Admission Board courses), ${ }^{6}$ where there was only one in 1960. Queensland will have at least five law schools, where there was only one until 1975. The intake into Victorian law schools will increase by at least 30 per cent by 1995-1996. ${ }^{7}$

Law schools are attractive propositions for universities, both public and private. Law schools carry the prestige of upper professional training and lead to linkages with the practising profession and the corporate sector; they attract the top-rated students in the tertiary pool, most of whom also will be obliged to spend half their time in another faculty; and they are very inexpensive to operate, particularly when compared with medicine, dentistry, veterinary science, engineering and other professional disciplines. The public universities in Australia have demonstrated that it is possible, although undesirable, to run legal education on a shoestring by having large classes, limited research funding, maintaining only basic law libraries, and avoiding clinical and other intensive (and thus expensive) programs.

Notwithstanding the increase in the number of law schools, the AVCC reports that there was unmet demand for a further 3000 places in Law in $1990 .^{8}$ This is despite considerable self-selection on the part of applicants, for the difficulty of getting into law school is quite well known. Neither does the figure take account of the potential demand for places by overseas students, particularly in the Asia-Pacific region. The pressure for places is not uniform there was a substantial increase in applications to study law in Victoria in 1991, while there was a small drop in the number of applications in New South Wales. ${ }^{9}$

There is no doubt that this demand is for programs which lead to a professional qualification in law, rather than merely some knowledge of law. For example, the minimum Tertiary Education Rank (ER) needed to gain admission to any of the LLB-granting law schools in New South Wales in 1991 was 95.40. However, it was possible to get into Newcastle University's Bachelor of Law and Administration program (which is not accepted for professional 
admission purposes) with a TER of 51.75, or just slightly more than was required for entry into the Arts Faculty. (Entry into Newcastle's medical school required a TER of 97.70.) In 1992, when Newcastle's law school begins to grant LLB degrees, it can be safely assumed that the TER will climb by at least 40 percentile ranks.

\section{Student Numbers}

The number of university law students in Australia more than doubled between 1950 and 1965 (to 3039), and then trebled between 1965 and 1980 (to 8,981) before funding cuts resulted in a slight dip (of about 200 places) over the course of the 1980s, to 8662 in $1989^{10}$ (see Table 1, below.) By comparison, there were 8907 students studying medicine in 1984. There were also 948 LLM students (747 by coursework) and $70 \mathrm{PhD}$ students in Law in 1989. ${ }^{11}$

The number of LLB students should begin to take off again shortly, with the establishment of the third wave law schools (see above), and sizable increases in the first year quota of some of the established law schools, such as Monash, ${ }^{12}$ Adelaide, the ANU and Western Australia. Little if any provision appears to have been made, however, for how this major increase in numbers will be catered for by the already stretched practical legal training institutions, which prepare law graduates for admission to practice.

As with practising lawyers, the great majority of law students are to be found in the largest states of New South Wales, Queensland and Victoria, compounding the geographic imbalance in the profession. For example, over the next five years the production of lawyers in New South Wales through all modes of legal education is likely to be two to three time higher than in Western Australia on a per capita basis. ${ }^{13}$ In 1989, 75 per cent of all Australian law/legal studies students were found in New South Wales (43\%), Queensland (20\%) and Victoria (12\%) combined. ${ }^{14}$ 
TABLE 1: Australian Law Student (LL B) Numbers, 1950-1989

\begin{tabular}{|c|c|}
\hline Year & Number of LLB students \\
\hline 1950 & 1466 \\
1960 & 2257 \\
1965 & 3039 \\
1975 & 7917 \\
1980 & 8981 \\
1984 & 8762 \\
1988 & 8119 \\
1989 & 8662 \\
\hline
\end{tabular}

Sources: 1950-1965 from census figures; 1975-1989 from the Universities Commission/CTEC/DEET.

Competition for places in the law schools is fierce, with all except the University of Tasmania maintaining quotas on entry for some years. Tasmania was forced to introduce a quota system for the first time from the beginning of 1989. Because of effective funding cuts, the number of places in Australia actually fell by about 200 between 1980 and 1985 while demand increased, correspondingly raising the cut-off marks for entry by school leavers. Even though there is a great deal of self-selection, based on expectations of examination scores and other factors, there were still over 20,000 applications in 1985 for about 2600 first year places in Law. ${ }^{15}$ In South Australia in 1986, there were over 1000 first preference applicants for only 120 places in Adelaide University's first year Law program. ${ }^{16}$ At Sydney University in 1987, there were over 1500 first preference applicants for 215 places in the law schoo1. ${ }^{17}$

In 1976, entry into any Australian law school was pretty well assured to an applicant who had finished in the top 15 per cent of school leavers; however, in 1985, entry to all law schools was limited to the top ten per cent of school leavers, and Melbourne, Sydney, Adelaide and New South Wales Universities only took the top several per cent. ${ }^{18}$ In 1991, a student in New South Wales needed to finish within the top two per cent to gain admission to the combined law degree programs at the University of New South Wales and Sydney University; within the top five per cent to get into Macquarie University, the University of Technology, Sydney, 
or Wollongong University's inaugural law class; and within the top six per cent to get into the ANU. ${ }^{19}$

\section{The Legal Profession}

One of the main features of the development of the modem Australian legal profession is the explosion of numbers over the past two decades. While numbers rose only modestly between 1911 and 1947 - and actually dropped slightly between 1933 and 1947 — there was a 600 per cent increase between 1947 and 1986, with much of that coming in the last decade. (See Table 2, below.)

TABLE 2: Number of Australian Lawyers, 1911-1986

\begin{tabular}{|c|c|}
\hline Year & Number of Lawyers \\
\hline 1911 & 2,955 \\
1933 & 4,345 \\
1947 & 4,329 \\
1961 & 6,636 \\
1975 & 12,580 \\
1986 & 26,007 \\
\hline
\end{tabular}

Sources: Australian Bureau of Statistics Census figures for 1911-1961 and 1986; 1975 figure from Disney et al., Lawyers (1977) 79.

The census figure for 1986 is somewhat higher than the legal professional associations recognise, since it includes those who self-identify as lawyers even though they may not all be holders of current practising certificates. Aggregating the figures supplied by all of the professional associations, there were close to 22,000 "practising lawyers" in Australia in mid-1985, about ten per cent of whom practised exclusively as barristers. Nearly three-quarters of these lawyers were located in New South Wales (9347) and Victoria (6134). These are by far the two most populous states, but they also have the lowest population-to-lawyer ratios. Whereas the legal profession did not grow as fast as the general population in Australia for the first half of this century, the ratio of population to lawyers has fallen significantly in all states and territories over the past 15 years. Overall, the figure is now under 700:1 nationally, down from 1750:1 in 1947, 1600:1 in 1968, and about 1000:1 in $1977 .{ }^{20}$ As indicated above, law school enrolments will ensure that the legal profession continues to expand at a rapid pace. 


\section{Employment Prospects for Graduates}

In the late 1970s and early 1980s, when the numbers of law graduates and admissions to practice reached new levels after the doubling of the number of law schools, almost all the forecasts for employment of law graduates were very pessimistic, talking in terms of "flood" and "over-supply". For example, the Bowen inquiry into legal education in New South Wales in 1979 recommended consideration of the reduction of student places, and saw this as a matter of some urgency, stating that "action to deal with an excessive output of lawyers involving a waste of resources should not wait upon definitive statistical studies proving the point conclusively."21 This recommendation was not implemented, and in the event the panic and projections turned out to be quite wrong, such that the Pearce Report in 1987 was able to predict that there would be a continued demand for law graduates and a widening field of employment. ${ }^{22}$

Notwithstanding the palpably increased anxiety among law students, recent graduates have a remarkable employment record. The Graduate Careers Council of Australia found that in the years 1983-1987, over 96 per cent of law graduates were in full-time employment within months after graduation. This record is surpassed (very fractionally) only by graduates in accounting, medicine and dentistry. ${ }^{23}$ The Council's survey of all new university and college graduates in New South Wales in 1989 found that the highest growth rate in starting salaries was in Law, with salaries in 1989 being over 400 per cent of salaries in $1977 .^{24}$

One reason for the continued high rate of employment of law graduates is the increasing willingness and ability of lawyers to work outside of the traditional modes of private practice. The Commonwealth Department of Employment and Industrial Relations (DEIR) estimated in 1983 that 10-15 per cent of lawyers are employed by governments, while "surplus" law graduates "appear to be absorbed relatively easily into generalist administrative positions". ${ }^{25}$ The Pearce Report's survey of law graduates found that 25 per cent were in employment which was either "not essentially legal", or was "essentially legal” but not private practice or government lawyering. This work included teaching, legal publishing and employment within corporations. ${ }^{26}$ Another CTEC study found that some law graduates were also well 
placed to move into new areas of work: "high technology and growth in service industries will increase demand for tertiary graduates ... in the traditional professions (eg law and accountancy) with a competency in, and understanding of, new techniques." ${ }^{27}$ These days most law students are obliged to, or choose to, enrol in joint-degree programs, which provide graduates with an additional qualification in arts, commerce or science and enlarge the ambit of employment opportunities. ${ }^{28}$

\section{SOCIAL BACKGROUND OF LAW STUDENTS}

\section{General Issues}

The Australian legal profession does not reflect the socioeconomic class, ethnicity or gender composition of the society at large. The recent huge expansion in numbers has resulted in a very young profession. The other key demographic shift has been in the significant increase in the number and proportion of women lawyers. However, the social background of young lawyers is, if anything, more elite than in previous generations.

As will be detailed below, the university law schools largely cater for a very select segment of society. University law students typically come from homes which are significantly more affluent than the norm; most attended selective or elite, private secondary schools; their parents mainly have professional or management backgrounds, and many already have family connections in the legal profession.

On the other hand, the Australian legal profession has traditionally allowed entrants to qualify for admission by means other than fulltime university study. Thus the Law Society of New South Wales can argue with some force that:

traditionally it has probably been easier for people from lower socioeconomic backgrounds to enter the legal profession than any of the other major professions ...

[A]ny person who could pass the necessary qualifying examinations [of the Admission Boards] could obtain entrance to the profession and such entrance was not confined to the sector of the community that could afford a lengthy period at University whilst not deriving any income. ${ }^{29}$

In the past twenty years, however, apprenticeship and other alternative modes of entry have been steadily phased out or reduced in importance, while university law schools have achieved 
centrality in providing legal qualifications. The levelling off of available places in the law schools coupled with increased demand has created a highly competitive situation whereby applicants in New South Wales, for example, must finish in the top few per cent of Higher School Certificate (HSC) examinees in order to be confident of admission - and must finish within the top two percent to be in a position to choose among the law schools. The number of women applicants has increased greatly in the past decade and, since these women are drawn from the same social class as male students, this has had the effect of doubling the number of upper-socio-economic-class aspirants.

\section{Gender}

It has been true in Australia, as elsewhere, that for some time now there have been: as many women employed in the general provision of legal services as there are men. However, while men occupy the lucrative and prestige-carrying sectors of legal work, women are employed to do the secretarial and reception work. ${ }^{30}$

The position began to change early in this century. ${ }^{31}$ Victoria was the first to remove (by legislation) the legal bar to the admission of women, in 1903, followed by Tasmania (1901)) Queensland (1905) and South Australia (1911). New South Wales did not remove the gender bar until 1918, ${ }^{32}$ although this was one year earlier than in England, and Western Australia followed later in 1923.

Only a few women were admitted to practice each decade until the 1950s, with the significant changes in the number of women lawyers and law students beginning in the 1960s. From that time, the number and proportion of women in law have both increased markedly. For example, between 1976 and 1981 there was a 28 per cent increase in the number of male solicitors in New South Wales, while there was an 165 per cent increase in the number of women solicitors, ${ }^{33}$ which nearly doubled the overall proportion of women. Starting from such a disadvantage, however, it will be at least several more years before women lawyers reach the 25 per cent mark nationally. (See Table 3, below.) 
TABLE 3: Women Lawyers in Australia, 1911-1986

\begin{tabular}{|c|c|c|}
\hline Year & $\begin{array}{c}\text { No. of Women } \\
\text { Lawyers }\end{array}$ & $\begin{array}{c}\text { \% of All } \\
\text { Lawyers }\end{array}$ \\
\hline 1911 & 6 & 0.2 \\
\hline 1933 & 49 & 1.1 \\
\hline 1947 & 109 & 2.6 \\
\hline 1971 & 618 & 6.0 \\
\hline 1986 & 4473 & 17.2 \\
\hline
\end{tabular}

Sources: Australian Bureau of Statistics national census figures.

Further details are available about the growth patterns of women in the local legal professions in Australia. In New South Wales, the proportion of women solicitors rose from one per cent in 1950 to six percent in 1975, then more than doubled to 13.7 per cent in 1984, and increased to 19.9 per cent in 1988. The proportion of women at the Bar rose from three per cent in 1975 to eight per cent in $1988 .^{34}$ The figures are similar across the states. For example, women were three per cent of legal practitioners in Western Australia in 1952, and 14 per cent in 1984, including five per cent of the separate Bar. ${ }^{35}$

The increase in the number of women lawyers is, of course, a flow-on from the number of women studying law, and enrolments of women have risen sharply over the past twenty years in Australia. Women comprised only 11.4 per cent of Australian university law students in 1960, 12.4 per cent in 1968, 22.1 per cent in 1974, 29.1 per cent in 1977, ${ }^{36} 33.3$ per cent in 1980, and 41 per cent in $1984 .{ }^{37}$ This latter figure was precisely the same as for women in university studies generally, ${ }^{38}$ and was higher than most other professional faculties, especially engineering. ${ }^{39}$ The figure in 1989 rose to 46.7 per cent, and the 1990 s should see the first 50.50 division.

While all of the statistics clearly indicate that the feminisation of the Australian legal profession is one of the most important developments of the modern profession, the increased proportion of women apparently will not affect class composition. Studies in Austra1ia, ${ }^{40}$ and overseas, demonstrate clearly and consistently that "women are drawn, even more than men, from professional and managerial families with large incomes and high levels of parental education."41 The spouses of women lawyers are also far more 
likely to be high status professionals or managers than the spouses of male lawyers. ${ }^{42}$

\section{Race and Ethnicity}

The legal professional associations and admission authorities do not keep records of race or ethnicity, and most surveys have called for country of birth rather than ethnic identification. These surveys have shown Australian lawyers overwhelmingly are Australianborn, with most of the foreign-born lawyers coming from the United Kingdom, Ireland, New Zealand or other English-speaking countries. Over 88 per cent of New South Wales lawyers were born in Australia (and nearly 80 per cent of the lawyers' fathers were Australia-born). Suburban solicitors were most likely to be foreignborn (17.5\%), while country solicitors were almost all (97.8\%) Australian-born. ${ }^{43}$ These figures are similar for the Victorian profession. ${ }^{44}$ With respect to the two major migrant groups in Victoria, a survey revealed that only 2.7 per cent of lawyers had Italian-born fathers and 0.8 per cent had Greek-born fathers, compared with 5.5 per cent and 3.4 per cent respectively of the adult male workforce generally. ${ }^{45}$ The Pearce Committee's survey of recent law graduates also found that 87 per cent were Australianborn and another eight per cent were from other English-speaking countries. $^{46}$

The per capita representation of migrant groups in the legal profession should continue to rise, given that participation rates in university education tend to increase with duration of residence. ${ }^{47}$ However, the substantial changes in the post-war ethnic composition of urban Australia have not yet fully flowed through to the legal profession, much less the judiciary. A national study of the social composition of the judiciary. A national study of the social composition of all tertiary students found that law schools had among the highest proportions of Australian-born students. ${ }^{48}$

A small number of Aboriginal lawyers have qualified, for the first time, in the past decade, assisted somewhat by special admission programs at the University of New South Wales, Queensland University and Monash University law schools. In 1986, six Aboriginal lawyers had been admitted to practice in New South Wales, two each in Victoria and Tasmania and one each in South Australia and the Northern Territory. There are now about 
twenty Aboriginal lawyers who are university trained, but there may be a few more who gained admission through apprenticeship or Admission Board schemes.

The survey of Victorian lawyers found a correlation between race/ethnicity and the types of work performed by lawyers. Virtually all lawyers practising in the high status, high reward areas of company and commercial law were Australian-born. In the relatively newer (and therefore more open) specialty of taxation law, 25 per cent of lawyers (and 42 per cent of their fathers) were foreign-born. ${ }^{49}$ However, this sort of correlation may have more to do with socio-economic considerations than sociocultural ones. Law students whose parents were born overseas were less likely to attend elite private schools, and their fathers typically had less formal education and lower occupational status. ${ }^{50}$ Migrant lawyers would also tend to lack the family and personal contacts in the profession that so many Australian-born lawyers have (see below), and thus miss out on an "important basis of social support role models and easier access to jobs in the profession. ${ }^{51}$

\section{Socio-Economic Class}

From the earliest days of the Inns of Court in England, the professional practice of law has been associated with the uppermiddle class. The variety of modes of entry into the profession did provide opportunities for "the especially able children of the poor". ${ }^{52}$ However, the decline of the non-university avenues to admission, such as apprenticeship and examination board programs, and the extreme competition for places at university, still make it very difficult for persons without advantaged backgrounds to enter into the profession. A recent, detailed study of participation rates in higher education in South Australia found that students from the upper one-third of the metropolitan population in socioeconomic terms were 20 times more likely to gain entry into medicine or law than students from the bottom third, and were five times more likely even to apply for admission to those faculties. ${ }^{53}$

In 1974, the Whitlam Labor Government abolished all tertiary tuition fees and instituted a student allowance scheme in an attempt to increase working class participation in higher education. ${ }^{54}$ However, follow-up studies have indicated "relatively little change in the socio-economic composition of students... If anything the 
balance has shifted marginally over time in favour of those from higher socio-economic back grounds. ${ }^{55}$ It is much less clear, however, whether the fee abolition experiment should be classed a failure, as the current Labor Government - especially the Education Minister, John Dawkins - is so oddly insistent upon doing. ${ }^{56}$ The participation rate of women and mature age students did increase markedly during this period, for example. Further, the decline of state-funded teacher cadetships; economic recessions and the massive reduction in youth employment opportunities; the significant rise in school retention rates and the consequent increased competition for tertiary places, ${ }^{57}$ and the great decrease in real terms of financial assistance to tertiary students, were all important countevailing factors. Given this situation, and the contraction of the working class as a proportion of society, ${ }^{58}$ the abolition of fees was probably essential to maintaining the participation rate of lower income and other disadvantaged persons, which would otherwise have dropped to trace levels.

Even within the elite world of the university, "medicine and law reflect by far the most extreme (socio-economic) discrimination levels, not only for student enrolments but also for applications”. ${ }^{59}$ Social background also appears to play a part in predisposing some students toward legal studies. One study of Australian university students found that "students in the science and humanities streams choose medicine and law respectively if they are from high status families, engineering or teaching if they are from lower status families." 60

In a survey of students entering university law schools in 1986, over 36 per cent had fathers with tertiary degrees and 20 per cent with mothers holding degrees. ${ }^{61}$ At the same time, only about eight per cent of the total Australian workforce was qualified to at least' first-degree level. ${ }^{62}$ Law students are at least twice as likely as students in commerce, education, arts and engineering to have fathers with university degrees, and only medical students come from (slightly) better-educated family backgrounds. ${ }^{63}$

A striking feature of the Australian legal profession is the extent to which there are strong "hereditary and tribal aspects". ${ }^{64}$ A survey of practising lawyers in New South Wales found that about 40 per cent of barristers and 50 per cent of solicitors had legally qualified relatives, with private practitioners somewhat more likely than government or corporation employed lawyers to have other lawyers 
in the family. ${ }^{65} \mathrm{~A}$ Victorian survey ${ }^{66}$ found a similar pattern: nearly 40 per cent of practising lawyers had another lawyer in the family, and 13 per cent had two or more lawyer relatives (mainly spouses, brothers and uncles). Over 15 percent had lawyer fathers, even though lawyers accounted for only about 0.3 per cent of the male workforce in Victoria. The 1986 entering law student survey also noted this correlation, but found that students in New South Wales and Victoria were somewhat more likely than students in other states to have a lawyer relative. ${ }^{67}$

The type of secondary schooling received is another peculiarly telling sociographic factor in Australia, with lawyers and other upper professionals drawn heavily from elite, expensive private schools and selective public schools. Among Western democracies, only Ireland has a greater proportion of children attending private schools, although in Ireland this is mainly for religious rather than class reasons. ${ }^{68}$ Australia also has a sizable systemic Catholic school population, but most elites are alumni of Protestant private schools (and some independent Catholic private schools). Surveys of lawyers and law students over the past few decades demonstrate gross over-representation of persons with private school backgrounds, especially those from the elite independent schools. One survey of students entering university in 1976 found that private school graduates were over-represented in all faculties, but especially in law and medicine. ${ }^{69}$ Fifty-five per cent of law student attended a private secondary school (29 per cent independent, 26 per cent Catholic), compared with 51 per cent of medical students, 37 per cent of science students, 40 per cent of commerce students, 39 per cent of arts students, 36 per cent of engineering students and 30 per cent of education students.

Goldring's survey of students entering law schools in New South Wales, Victoria and the ACT. in 1986 (and the Pearce Committee's commissioned national survey of law graduates) revealed that the position was unchanged. ${ }^{70}$ Only 41 per cent of law school entrants were from state schools, even though 62 percent of all Year 12 students in the preceding year were educated at state schools. Private school leavers accounted for 55 per cent of law school entrants (32 per cent independent schools, 23 per cent Catholic systemic schools), even though those schools produced only 39 per cent of that year's matriculants (26 per cent independent schools, 13 per cent Catholic systemic schools). The 
proportion of independent school students in Victoria was much greater than in New South Wales or the ACT. Women entrants were slightly more likely to have attended state schools.

Bradsen and Farrington's research into student selection and performance at Adelaide University's law school ${ }^{71}$ also makes the point very strongly. In 1985, 40 per cent of all school leavers entering into Law came from only four private schools, and 78 per cent came from only 12 private or Catholic schools. By contrast, independent schools provided only 17 per cent, and Catholic schools 16 per cent, of South Australia's matriculants in 1984, while the state school system produced 67 per cent. Even taking into account transfer students and other entrants who did not come straight from school, only 33 per cent of the entering class in 1985 had state school backgrounds.

The proportion of private school students entering law school is, if anything, likely to increase in future. An Australian Teachers Federation report ${ }^{72}$ says that between $1975-76$ and 1985-86, private school enrolments increased by 25 per cent, which represented a six per cent drift overall from the public schools to the private schools. This was no doubt occasioned in large part by greatly increased Commonwealth funding for private schools at the same time that funding to the public schools decreased and education funding generally dropped as a proportion of the federal budget. ${ }^{73}$ Recent studies by the New South Wales Government and the Australian Bureau of Statistics have found that a much higher proportion of private school students complete their secondary education than state school students (63\% vs $41.5 \%$ ), and private school students were three times as likely to attend university the year after finishing school. ${ }^{74}$

\section{Access Programs}

In recent years there have been strong expressions, at the governmental and institutional levels, of commitment to facilitate access to higher education by persons from disadvantaged backgrounds. In 1983, the Hawke Government announced the establishment of the Participation and Equity Program (PEP), aimed at improving the prospects of disadvantaged school students. A Secondary Allowances Scheme and Disadvantaged Schools Program were also instituted. In its Report for the 1985-1987 
Triennium, CTEC affirmed its policy that:

the student base be broadened in those professions, such as medicine and law, which are expected to serve all members of society. Aborigines, migrants and people from non-English speaking backgrounds and children from working class backgrounds, should be given reasonable chances to enter these faculties. We expect Institutions which have highly restricted faculties to undertake an urgent review of their existing selection arrangements, with a view to providing fairer opportunities for disadvantaged groups. ${ }^{75}$

The Australian Law School Deans also recently committed themselves to such a policy:

Law affects all members of the community irrespective of wealth, ethnic background, gender or any other social or individual difference. If the law is to respond to the needs of these different groups, lawyers themselves need to reflect the broadest possible social mix. ${ }^{76}$

Government actions - and funds - have not matched the rhetoric, however. Funding for higher education has declined substantially in real terms over the last decade, and has also declined substantially as a proportion of the federal budget and of GDP, even while the Commonwealth's investment in private secondary education has increased significant1y. ${ }^{77}$ The bridging courses that are essential to prepare disadvantaged students for tertiary studies have not been sufficiently funded either. The already poorly resourced law schools have neither the funds nor the specialist staff to mount such programs. ${ }^{78}$ The CTEC Triennium Report, while calling for access to professional programs, expressly avoided dealing with the question of funds for bridging courses, suggesting that such courses are within the province of the Technical and Further Education (TAFE) sector, which is a state rather than federal responsibility and is already very underresourced. $^{79}$

One area where limited bridging and support programs do exist, and have dramatically demonstrated their worth, is with respect to Aboriginal students. Aborigines are the most under-represented group in higher education. ${ }^{80}$ In 1984, only 13 per cent of Aboriginal students completed their full secondary education, and only 4.1 per cent of Aboriginals have some post-secondary educational qualification, compared with 24 per cent of the total workforce. In 1985, Aborigines comprised just over one per cent of the population, but represented only 0.07 per cent of university students and 0.3 per cent of college of advanced education 
students. ${ }^{81}$ Because of the small numbers of eligible persons and the history of dispossession and disadvantage, many law schools will admit Aboriginal students outside of quota restrictions. In 1987, there were 36 Aboriginal law students in Australia. The University of New South Wales, which admitted 34 Aboriginal law students between 1971 and 1985, and Monash and Queensland Universities have been most associated with special admission schemes for Aborigines.

Many law schools are now committed to providing special admission for a limited number of applicants from disadvantaged backgrounds. A number of strategies are available, some of them already in practice in limited degrees, which could open up access to law studies and the legal profession for persons from disadvantaged backgrounds. Simply increasing the number of places available will not shift the sociographic profile of the student body, as the experience of the past two decades indicates. In highly selective courses such as Law and Medicine the additional places will mostly be filled with students from the same socioeconomic background as those already enroled, who now become able to gain their first preference. ${ }^{82}$ A study conducted in South Australia ${ }^{83}$ showed that increasing the number of first year places at Adelaide University law school by 30 per cent would result in no appreciable change in the socio-economic composition of the incoming class in terms of gender, geographic origins (urban-rural), residence, parents' educational backgrounds, parents' occupations, and nonEnglish speaking home environment.

Greater equity could be achieved in politically and academically acceptable ways, however, by diversifying teaching and admissions policies to include relatively larger proportions of mature age students, transfer students from other faculties, and part-time and external students. Most law schools already have special admission schemes for mature age students, but enrol only small numbers in this category each year. ${ }^{84}$ There is strong evidence that admissions in this category serve an important social equity function. Over one-third of mature age entrants were early school leavers who came mainly from disadvantaged backgrounds, and used the special admission schemes as a "second chance" to improve their education and occupational opportunities. ${ }^{85}$ The Pearce Committee's review of legal education in Australia endorsed mature age entry as a method to broaden the social base of law 
students, but expressed concern about the significantly higher dropout rate of mature age students. ${ }^{86}$

Similarly, Goldring's study of the social background of Australian law students indicated that part-time and external students tended to come from less advantaged backgrounds than other law students. He concluded that "the most practical way" of achieving broader access to legal education "is by expanding the opportunities for part-time or distance education in law"87 since these types of courses are often the only ones which disadvantaged students can afford (in terms of direct expenses and foregone income) to pursue. Despite the imposition of the higher education tax ("HECS", see below) and other disincentives, there has been a very substantial rise in the number and proportion of applications for university entrance from mature age students in the past year. ${ }^{88}$ Of course, programs for these students need sufficient resources to permit development of special teaching methods and materials.

Another approach to access involves delaying entry into law schools for most or all students until after one year of studies in another faculty, with entry based on tertiary results rather than on school rankings. The law schools at the University of Tasmania and the University of Western Australia operated in this way for some time, although UWA has just moved towards first year intake. Adelaide adopted the delayed entry approach in 1987, and Sydney University, UNSW and Wollongong are moving in this direction, in principle. Such a scheme has two main advantages. First, the Bradsen and Farrington study of Adelaide law students found that tertiary results were a much better predictor of likely success in law studies than were school matriculation results. Even transfer students with matriculation marks far below those necessary to enter the Law Faculty on that basis were "expected to perform just as well, if not better, than those with high matriculation marks." 89

Equally important is the evidence that students from less advantaged backgrounds are able to "catch up" in the first year of tertiary studies. Students from state schools, for example, may improve their relative standing by five to seven per cent, which may make the difference in reaching the quota levels in competitive faculties such as Law. ${ }^{90}$ It is for these reasons that Adelaide changed its admissions policies from 1987, selecting students into Law after a one year preliminary general course at the university. The Pearce Committee suggested that all law schools give 
consideration to this selection scheme "as the principal means of entry for law studies", ${ }^{91}$ and the Australian Law Deans seem enthusiastic about this course of action as well. ${ }^{92}$

One negative side-effect of increasing the proportion of second year intake, however, is that the HSC cut-off marks get even higher, since demand from school leavers for places is constant (at least) while the number of places reserved for these students in the quota decreases. These marks are widely reported in the media ${ }^{93}$ with little accompanying explanation, intensifying the view that you have got to be a "brain" to get into law school and thus discouraging many worthy applicants - particularly those without the social confidence to believe that they "deserve" a place in Law.

Nevertheless, second year intake (particularly if this is the exclusive mode of entry for undergraduates) appears to be a more effective strategy than simply reducing entry requirements for disadvantaged students. A number of law schools currently have access programs which admit disadvantaged students whose HSC aggregates are within 30 points of the normal cut-off mark for the quota. However, this has only a marginal impact in highly competitive faculties, such as Law. In 1991, the HSC aggregate required for entry into Law at the University of New South Wales was 452, ahead of Medicine (447) and well over 100 points above the mark needed for general matriculation or acceptance into the Applied Science, Science (276), Surveying, Building, Social Work, Arts (300) and almost all of the Engineering courses.

Even with a 30 mark benefit, ACCESS students would have needed a higher aggregate to enter Law than was required for ordinary students to enter any course except Medicine, Computer Science or Optometry, and this is clearly well beyond the reach of students who by definition have suffered significant educational disadvantage. Accordingly, the UNSW Law School endorsed the ethos of the ACCESS Scheme, but suggested that in practice it would be necessary to defer consideration of ACCESS applicants until after one year of studies in another faculty. ${ }^{94}$ ACCESS students interested in law would be able to gain admission into Arts, say, with a mark as low as 304 (in 1990), and if their performance in first year was satisfactory they would be able to transfer into Law. 


\section{FUNDING ISSUES}

In the past few years, higher education generally has undergone the biggest shake-up since the 1960s, when the system expanded exponentially and the Commonwealth took over funding. Led on this issue by John Dawkins, the Minister for Employment, Education and Training, the federal Labor Government has set about restructuring most aspects of the tertiary system, including funding arrangements, staffing arrangements, educational and research priorities, and the effective ending of the binary system (of universities and colleges). The new vision is detailed in a series of documents over a short period of time, from the Minister's 'The Challenge for Higher Education in Australia” in November 1987, the release of a Government Green Paper in February 1988, ${ }^{95}$ a report on funding through new fee and taxation plans (the Wran Report) in April 1988, ${ }^{96}$ and finally the release of the Government's White Paper in late July $1988 .{ }^{97}$

The new system calls for another major expansion of student numbers, with 20,000 new places being created in the next few years and double that by the turn of the century. Government strategy has been to increase the number of places at the same time that funding is decreasing in real terms, which is the problem at the heart of the present crisis in tertiary education. Funding per fulltime student is now "a staggering 23 to 25 per cent less ... than 15 years ago". 98

Little of the expansion was intended to be in Law. The Minister has on a number of occasions referred to the "oversupply" of lawyers and doctors (without presenting evidence of this), and the White Paper specifies "national priorities" — and therefore funding priorities and student places'- in the areas of engineering (especially industrial) and technology, computer science, accounting and business management, and Asian studies. This vocationally-oriented, instrumental approach to higher education is supported in the Green Paper by numerous charts and graphs, but regrettably little in the way of compelling analysis or principle. ${ }^{99}$

The White Paper does not contain a single reference to law or legal education, nor even generally to the challenge of providing a proper education for professionals.

Although the Australian Labor Party's policy platform used to call for "free" tertiary education, the Party's national conference in 
June 1988 replaced this with an undertaking to "ensure that all qualified Australians will have access to a tertiary education regardless of their means”. This shift allowed for implementation of key aspects of the Wran Report, which recommended that expansion be funded by a user-pays system, with "contributions by individual beneficiaries of higher education average around 20 per cent of course costs”, payable as a tax levy after studies have ended (whether a degree was taken out or not). ${ }^{100}$ Under the Wran plan, tax debits would have accrued at a rate of $\$ 3000$ per year for students in "expensive" courses such as medicine, dentistry, veterinary science and agriculture; $\$ 2500$ per year for students in engineering, surveying and certain science courses; and \$1500 per year for all other courses, including Law. ${ }^{101}$ However, the plan approved by the ERC which is now the law provides for a flat charge of $\$ 1800$ per year for all courses, indexed annually, and payable by a one-to-three per cent surtax which slides with income.

Although easier to administer, the new scheme is anomalous on its own user-pays terms. The cost per degree in Law, given the severe under-resourcing of Australian law schools, is \$12,143 (in 1988 dollars), but law students who do five-year combined degrees will apparently be asked to repay $\$ 9,000$ (with the amount subject to indexation). Students in engineering, medicine and veterinary science will repay the 'same amount even though their degrees cost the taxpayers \$31,209, \$53393 and \$69,845 respectively. ${ }^{102}$

Nevertheless, the Pearce Report confirms that law schools have the worst staffing levels of any university discipline. ${ }^{103}$ In 1985, the average student-staff ratio in Australian universities was 14:1; in Law the average was 20:1, with Sydney University Law School suffering under a ratio of 32:l. The Pearce Report offered an historical explanation for the current inadequate and inequitable funding position: Law had only relatively recently moved from apprenticeship-based vocational training to a recognised academic discipline; and law schools had previously been content to rely on part-time teachers from the profession and large lectures (plus articles for practical training), to maintain small and narrowly focussed libraries and to eschew research funding (and activity).

The Pearce Committee found that the University of New South Wales had "the only law school in Australia that is resourced to a level comparable with Arts faculties"104 and thus was the only law school able simultaneously to engage in "small” group teaching, 
professional skills development, clinical training, and exploration of policy and social issues. (Sadly, UNSW Law School's financial situation has declined substantially since the publication of the Pearce Report, the student-staff ratio has risen, and many of the most lauded programs are now under threat. This highlights the hollowness of one of the promised beneficial features of the new unified system of tertiary education promoted by Mr Dawkins that there would be healthy competition, with the better performed schools attracting more resources.) Arts faculties in Australia are themselves relatively poorly resourced compared with those in medicine, science and technology, so the ambition of law schools to achieve parity with Arts is hardly overweening.

The financial position of law schools is unlikely to improve in the near future, and may deteriorate further. The federal Department of Employment, Education and Training (DEET) has proposed a new formula for tertiary funding based on "Relative Teaching Costs", with all academic disciplines slotted into one of five clusters. ${ }^{105}$ Law, with Commerce and the other humanities, is placed in Cluster 1, the lowest funding category:

- In Cluster 1, universities will receive only about $\$ 4,000$ per Equivalent Full-Time Student Unit (EFTSU).

- Cluster 2 disciplines will be funded at 1.25 the base rate (Cluster 1), or about \$5,000 per EFTSU, and includes Education, Maths and Social and Behavioural Sciences.

- Cluster 3, funded at 1.45 times the base rate (about \$5,800 per EFTSU), includes Computing, Nursing, Languages, Architecture and Visual and Performing Arts.

- Cluster 4, funded at 2.2 times the base rate $(\$ 8,000)$, includes Engineering, Sciences and Surveying.

- Cluster 5, funded at 2.95 times the base rate $(\$ 11,800)$, includes Agriculture, Medicine, Dentistry and Veterinary Science.

Assuming that a university administration takes up to 40 per cent of this for central costs, as is often the case now with income from student fees, law schools will receive only about \$2,400 per EFTSU. Further, for students doing combined degrees — now the majority of all law students - law schools will only gain the benefit of the total EFEU weighting in the third or fourth year of studies.

The intellectual assumptions which underpin this categorisation are elusive, if not fraudulent. The relegation of Law to Cluster 1 
suggests that the decision-makers have no understanding or experience of the practice of law teaching, and that the Pearce Report's call for more clinical education and professional skills training (drafting and interpretation, negotiation, advocacy, ethics, etc.) in Australian law schools will not be heeded.

It is unimaginable that the Government would mandate that Australian doctors be educated solely through passive attendance at lectures, without the opportunity for extensive clinical practice in teaching hospitals, exposure to community medicine, time spent in the laboratory and so on. Yet the positioning of Law in Cluster 1 mandates that Australian lawyers be trained as cheaply as possible, which means the large' lecture hall mode. Faculties wishing to do anything more labour-intensive will be required to gain outside funding or to continue to subsidise the cost themselves through the further deterioration of working conditions. Yet outside funding whether from student fees or from private donors - will inevitably change university culture and decrease academic autonomy, as decision-making becomes more influenced by economic considerations than educational ones.

It is a matter of the greatest regret that just at the time when Australian law teachers have begun to explore the pedagogical issues and challenges of their discipline with a degree of energy and creativity, ${ }^{106}$ financial concerns are likely to overwhelm all else.

The Deans of the law schools in New South Wales and the Director of the College of Law have called upon the Commonwealth Government to abandon the proposed DEET funding formula and to recognise that law schools should be funded on the basis that certain "minimum adequate standards" be met, such as: an overall student-staff ratio of 15:1 (which is still higher than the general university average); provision of a clinical and skills component in legal education, for which the ratio should be no higher than 8:1; sufficient levels of remuneration to attract and keep qualified staff; provision of adequate law library collections; and adequate building and infrastructure, including computer access. ${ }^{107}$ That the Law Deans must make this plaintive plea for such a modest vision of legal education in Australia is disturbing. That the achievement of this modest vision is impossible in the present circumstances is disgraceful.

The sad irony for Australian law schools in the public 
universities is that while they attract the most academically accomplished students in the pool each year, and these students come from very affluent backgrounds and mainly attended expensive, private secondary schools (see above), the law schools are not permitted to charge them even modest fees in order to gain sufficient resources to give these students an intellectually challenging and professionally effective education. Given that public funding is unlikely to increase and private donations are insufficient and too erratic to depend upon for recurrent budget items, it may be that the only escape route for the law schools is to seek permission to charge fees (which, unlike the HECS contributions, must go directly to the faculty involved), with a system of waivers or scholarships for those who are genuinely unable to pay.

The development of more private law schools will no doubt hasten this process. For example, Bond University currently charges LLB students $\$ 12,000$ per two semesters. ${ }^{108}$ In 1991 , the public universities received only a notional \$5056 from the federal government for each full-time law student, of which about $\$ 3500$ actually made its way to the law schools themselves. This “Dawkins Gap" of about $\$ 7000$ per law student per year, as the head of the Australian Law Deans group, Prof David Flint, has referred to it, manifests itself in "low academic salaries, high staff student ratios, emasculated libraries, and an overall air of decline”. 109

The position with respect to research funding is no more optimistic. The "claw-back of research money from the universities to the central Australian Research Council (ARC) particularly disadvantages legal academics. The two things most necessary to assist most legal scholars are time and library resources, neither of which are readily acquired with ARC grants. The nature and practice of the centralised grant system reflect a paradigm of research which ill-suits legal scholars, rewarding the grand, multiparty, networked, heavy-on-equipment, style of proposal.

Concern over the details of funding for law teaching and research presupposes that there will actually be staff willing and qualified to undertake these activities.

Numerous recent studies have all pointed to the serious erosion of academic salaries since 1973 and the likelihood of a severe shortage of qualified academic staff in all disciplines by the middle 
of the decade. A very recent report ${ }^{110}$ by the National Institute of Labour Studies, commissioned by the Commonwealth Department of Employment, Education and Training, estimates that there will be a shortfall of between 16,000-24,000 academics in Australia by the year 2001 (depending upon the rate of student growth). Law, especially commercial law, is among the areas identified in the Report as experiencing “acute current recruitment difficulties”, in large part because of the "substantial gaps between academic and private sector salaries". ${ }^{111}$ The Report also found that the poor academic salaries relative to other developed countries means that overseas recruitment "is becoming increasingly sourced from 'refugee' sources — South Africa, Hong Kong, China, etc.”112 And, indeed, following release of the Report, steps are already being taken to streamline entry visa procedures for overseas-recruited academics. $^{113}$

Academic salaries in Australia have fallen by more than 25 per cent in relation to the cost of living, by 33 per cent in relation to average earnings, by 8 per cent in relation to CSIRO scientists and public engineers (traditional comparitors in the centralised wagefixing system), and by $10-50$ per cent in relation to average academic salaries in the United States, the United Kingdom, New Zealand and Canada. Merely to restore Australian academics to their 1974 levels of pay would require immediate pay rises of 2127 per cent. A professor would be earning just over $\$ 100,000$ rather than $\$ 65,000$; a senior lecturer $\$ 73,000$ rather than $\$ 49,000$; a lecturer $\$ 44,000$ instead of $\$ 32,000 .^{114}$ Even if the award restructuring pay claim proposals by the academic unions currently before the Industrial Relations Commission are accepted in toto and then fully funded by the Commonwealth Government, this would only go a small way toward redressing the problem. ${ }^{115}$

In 1973, a professor earned 2.73 times average weekly earnings (AWE) net of tax, and a lecturer earned 1.52 times AWE. In 1988, however, a professor earned only 1.88 times AWE and a lecturer only 1.06 times AWE. ${ }^{116}$ Just a decade ago, professorial salaries were on par with those of the judiciary. By 1988, professorial salaries had fallen to two-thirds those of NSW District Court judges. By late 1990, a law professor earned less than a magistrate, only half the salary of the same District Court judge, and substantially less than more senior judges. ${ }^{117}$ Yet it is now a matter of frequent public comment by Attorneys-General and presiding 
judges that it is very difficult to recruit judges from the private profession because of the large drop in income that would be involved.

This collapse of academic salaries and conditions has accelerated the turnover of legal academic staff and made it very difficult to compete with private law firms and even other parts of the public sector (such as law reform commissions, statutory authorities, and Attorney-General's departments) for the services of top graduates. ${ }^{118}$ Recruitment of experienced legal practitioners, particularly in areas where private practice is most lucrative, is almost impossible. ${ }^{119}$ The position in the United Kingdom is similarly critical, even though salaries have risen more there during the same period. 127 British university law teachers - 25 per cent of all legal academics — left academia between 1984 and 1988. Most went into private practice, with the rest going to the public service, the EC, and industry and commerce. ${ }^{120}$

In late 1988, the federal Remuneration Tribunal recommended huge salary rises for federal judges, largely on the basis of comparative wage justice principles which had been abandoned for the rest of the workforce under the Accord. For example, it was recommended that the salary of the Chief Justice of the High Court rise 81 per cent from $\$ 127,000$ to $\$ 230,000$; a Federal Court judge from $\$ 98,000$ to $\$ 180,000$; and a Family Court judge from $\$ 88,000$ to $\$ 162,000$. The Tribunal justified these rises partly on the basis that: (1) the low level of judicial salaries would lower the standing of the judiciary in the eyes of the community; and (2) it was a matter of some embarrassment to judges that their income was often lower than the lawyers who appeared before them and "these facts are known to all concerned". ${ }^{121}$

If this is so, imagine the embarrassment of a senior lecturer in law with several university degrees, ten or more years of teaching experience, an excellent record of scholarship, and a competitivelywon promotion, who finds that his or her students are offered higher salaries by corporate law firms immediately upon graduation. More to the point, imagine the difficulty of recruiting for a lectureship someone with excellent academic qualifications and several years of practical experience (and perhaps partnership prospects) in such areas as companies law or taxation. It is cold comfort to law deans - and law students - that the problems are equally acute in accounting and some other professional 


\section{disciplines.}

In a society which tends to measure worth and prestige largely in terms of income (as the judges have recognised), academic work is thus devalued as well as poorly paid.

* Commissioner, New South Wales Law Reform Commission. This article is based on a paper delivered at a national Conference on Legal Education in February 1991 at Bond University.

(C) 1991. (1990-91) 2 Legal Educ Review 219.

1 D Pearce, E Campbell and D Harding, Australian Law Schools: A Discipline Assessment for the Commonwealth Tertiary Education Commission (Canberra: Australian Government Publishing Service, 1987) (hereafter, the "Pearce Report'?.

2 W West, Victorians catching up in law race, The Australian, Feb 27, 1991 at 17.

3 J Poprzeczny, US Law Dean Heads Notre Dame Team, The Australian, Sept 5, 1990 at 18.

$4 \mathrm{~J}$ Cribb, Next private university opens in '91, The Australian, Oct 23, 1990 at 3.

5 Report of the Committee on the Future of Tertiary Education in Australia (1964) (“The Martin Report”), Part II, 49.

6 Sydney, UNSW, Macquarie, UTS, Wollongong, Newcastle, and the ANU, plus the Australian Catholic University, Hastings International, New England, Canberra and University of Western Sydney.

7 West, supra note 2.

8 W West, Students still shun high-tech subjects, The Australian, Aug 8, 1990 at 31.

9 See D Thorp and S Wilson, Business Studies In Doldrums, The Australian, Jan 19, 1991 at 13. First choice applications for law at Monash rose by 36 per cent; at Melbourne applications rose by 14 per cent in law generally and 25 per cent in Arts/Law. Applications for law fell by 7 per cent at Sydney and 5 per cent at UNSW; however, the new law school at Wollongong may have picked up some of those preferences.

10 See D Weisbrot, Australian Lawyers (1990) 64. For the 1989 figures, see DEET, Selected Higher Education Statistics 1989 (1990) 31, Table 2.

11 Id.

12 Monash increased its first-year intake by 50 per cent to 465 in 1991 . See W West, Monash expands its legal horizons, The Australian, Oct 171990 at 17.

13 Id at 259.

14 DEET, supra note 10 , Table 3.

15 Pearce Report, supra note 1 , at 470.

16 JR Bradsen and JA Farrington, Student selection and performance in the Faculty of Law, the University of Adelaide, (1986) 29(1) Austrl U Rev 25.

17 Sydney Morning Herald, Sept 231987 at 12.

18 Pearce Report, supra note 10, at 471 and 474.

19 The precise Tertiary Education Rankings (TER) for 1991 are: UNSW, 98.55; Sydney, 98.25; Macquarie, 95.80; Wollongong and UTS, 95.40; and the ANU, 94.10 .

20 For a much more detailed breakdown, see D Weisbrot, supra note 10, at 62-64, and D Weisbrot, The Australian Legal Profession: From Provincial Family Firms to Multinationals, in R Abel and P Lewis (eds), Lawyers in Society The Common Law World, (Vol 1, Berkeley: University of California Press, 1988) 244, at 303, Table 6.1.

Report of the Committee of Inquiry into Legal Education in New South Wales 
(1979) (“the Bowen Report”) 61. See also CW Pincus, Future Employment of Lawyers, (1980) Queensland L Sac 145; and TW Beed and IG Campbell, Supply and Demand Factors Associated with the Legal Profession in New South Wales, University of Sydney Sample Survey Centre Occasional Paper No 1 (1977) R-73. Pearce Report, supra note 1, at 528.

Graduate Careers Council of Australia, 1986 Australian Graduates in 1987: Activities as at 30 April, (1987).

P Totaro, NSW graduates top earning league, Sydney Morning Herald, Sept 26, 1990 at 6 . Law graduates $(\$ 23,300)$ still trailed well behind dentists $(\$ 32,000)$ and doctors and optometrists $(\$ 28,000)$ in starting salaries, however.

DEIR, Employment Prospects by Industry and Occupation (Canberra: Australian Government Publishing Service 1983) 89.

Pearce Report, supra note 1, at 24.

CTEC, Labour Market Factors Affecting Demand for Tertiary Education (Canberra: Commonwealth Tertiary Education Commission 1986) para 19.

Pearce Report, supra note 1 at 71. New joint degree programs also are being developed to include social work, computer science, engineering and other disciplines.

Law Society of New South Wales, Composition of the Profession (1978, Submission to the NSW Law Reform Commission) 14.

A Sachs and J Wilson, Sexism and the Law (Oxford, Eng: M Robertson 1978) 177.

See J Mathews, The Changing Profile of Women in the Law, (1982) 56 Austl L J 634.

Women's Legal Status Act 1918 (NSW). This Act also removed prohibitions on women becoming judges, magistrates, justices of the peace, and members of state parliament and local government councils. Id.

Sources: 1911 census; 1940-1975 from J Disney, J Basten, P Redmond and S Ross, Lawyers (Sydney: Law Book Co 1977 at 188; 1981-1987 from the NSW Law Society, Bar Association and Women Lawyers Association.

J Musk, An Overview of Women in the Legal Profession, (Sept 1984) Brief 6.

R Tomasic, Social Organisation Amongst Australian Lawyers, (1983) 19 Austl NZJ of Soc 447 at 451; Mathews, supra note 31; and M Kirby, The Women Are Coming, (1982) Austl L News 11.

Pearce Report, supra note 1 , at 451.

Australian Bureau of Statistics, Tertiary Education, New South Wales 1983 (1984) at 15.

For example, at the University of New South Wales in 1987, the percentage of women entering the various faculties was as follows: Applied Science 36\%; Architecture 44\%; Arts 66\%; Science 48\%; Commerce (includes accounting) 46\%; Engineering 8\%; Law 48\%; Medicine 40\%; and Professional Studies 76\% (includes social work and librarianship). See $\mathrm{H}$ Simpson, Profile of $\mathrm{New}$ Undergraduate Students Enroled at the University of New South Wales 1987: A Comparison with 1974, (Tertiary Education Research Centre, UNSW, Research and Development Paper No 67, September 1987) at 1, Table 1.

DS Anderson and JS Western, Social Profiles of Students in Four Professions, (1970) 3(4) Q Rev of Austl Educ 1, 20; M Hetherton, Victoria's Lawyers Second Report (Melbourne: Victoria Law Foundation 1981) at 116; and K Ziegert, Students in Law Moot: Some Data on the Accumulation of Advantage, (unpublished, Sydney University Department of Jurisprudence, 1983) at 9.

Id at 20.

B Winter, Women Lawyers Work Harder, Are Paid Less, but They're Happy, (1983) 69 ABAJ 1384. 

21-23.

44 M Hetherton, Victoria's Lawyers (1978) 15-17.

$45 I d$, at 16, Table 2.4 .

46 Pearce Report, supra note 1, Vol 4 at 20, Tables 2.4-2.5.

47 Anderson and Western, supra note 40, at 22.

48 D Anderson, R Boven, PJ Fensham \& JP Powell, Students in Australian Higher Education: A Study of Their Social Composition Since the Abolition of Fees (Canberra: Australian Government Publishing Service 1980) at 93. Law was second to Education and just ahead of Medicine in the percentage of Australianborn students. At the University of New South Wales in 1985, law students were the most Australian-born of any faculty, with 81 per cent. This compares with 71 per cent of all students, and 62 per cent in medicine, 73 per cent in architecture and 60 per cent in education. Hetherton, supra note 40, at 34-35.

50 Ziegert, supra note 40, at 22-24.

51 R Tomasic, Lawyers and Social Control - A Preliminary Inquiry, (1983) 3 Windsor Yearbook of Access to Justice 20, at 47.

52 FC Hutley, unpublished submission to the NSW Law Reform Commission, 29 April 1977, at 10.

53 RD Linke, LM Oertel \& NJM Kelsey, Participation and Equity in Higher Education: A Preliminary Report on the Socio-economic Profile of Higher Education Students in South Australia 1974-1984, (1985) 11(3) Austl Bull of Lab 124 at 138.

G Whitlam, The Whitlam Government 1972-1975 (Ringwood, Vic: Viking, 1985 simultaneously published Ringwood, Vic: Penguin 1985) at 323.

RD Linke, 'The Facts of the Matter - Equality: Forwards or Backwards?" (paper presented at a seminar on Access to Higher Education, at the ANU, Canberra, 3 Dec 1987) 4. See also Linke, supra note 53, at 87; Anderson supra note 48; D5 Anderson and AE Vervorn, Access to Privilege: Patterns of Participation in Australian Post-Secondary Education (1983) 129-149; and articles in (1987) 13(2) Austl Bull of Lab 108-125.

See eg, Dawkins questions free education's value to the poor, Sydney Morning Herald, Oct 81987 at 3; and Free tertiary education a failure, says Dawkins, Sydney Morning Herald, May 51988 at 2.

57 Linke, supra note 55, at 5.

58 C McGregor, Labor excludes its own, Sydney Morning Herald, June 6, 1988 at 15.

59 Linke, supra note 53, at 138.

60 Anderson and Western, supra note 40, at 24.

61 J Goldring, An Updated Social Profile of Students Entering Law Courses, Pearce Report, Appendix 4, supra note 1 at 7. In 1976, the figures were $28 \%$ and $11.2 \%$, respectively.

62 Not enough graduates, industry forum told, Sydney Morning Herald, Mar 30, 1987 at 5 .

63 Anderson, Boven, Fensham \& Powell, supra note 48, at 77.

64 M Sexton and L Maher, The Legal Mystique: The Role of Lawyers in Australian Society (Sydney: Angus \& Robertson 1982) at 8.

65 Tomasic and Bullard, supra note 43, at 23 and 177.

66 Hetherton supra note 44, at 15.

67 Goldring, supra note 61. See also the survey of law graduates in the Pearce Report, supra note 1 , at Vol 4, at 81. Twenty-seven per cent of graduates reported that they had at least one dose relative in the legal profession. 
P Smark and J Whelan, A Middle-Class Dilemma: How to Educate Kate and James, Sydney Morning Herald, July 22, 1985 at 4.

69

\section{4,23-24, respectively.}

71 Bradsen and Farrington, supra note 16, at 31. A rough residential division of Adelaide also indicated that "the more affluent eastern/north Adelaide areas are particularly strongly represented in the Law School.” Id. See also C Power, F Robertson and M Baker, Access to Higher Education: Participation, Equity and Policy (CTEC, 1986) 97-103. This study was of entry (and non-entry) into higher education in South Australia in 1985, and found that law, with medicine, architecture and fine arts, stood out "as the courses which are most elitist in terms of students' family background. Id at 100 . More than half of law students attended independent secondary schools (53\%, and 18\% Catholic) and had fathers with degrees who were professionals. The average income of law student's parents was significantly higher than in any other course, and a far greater proportion of law students (27\%) were in the top income bracket (more than $\$ 50,000)$. Id at 144 , Table 7.3.

Trends in Commonwealth Spending in Schools, discussed in A Susskind, Funding to private school; up 123 pc, Sydney Morning Herald, July 31, 1987 at 4.

73 Id, and see MD Kirby, Recession, Law Reform and Education, (1983) 13 Queensland L Soc 162, at 68-69.

74 W Jamrozik, Children of the State learn in private, Sydney Morning Herald, Dec 31,1987 at 3 .

75 Volume 1, 59, paras 3.77-3.78. See also ch 3 of the Report of the Committee of Enquiry, Review of Efficiency and Effectiveness in Higher Education (1986), esp at 94 . Discussion Paper (Green Paper) (May 1988), 5.

C Power, F Roberton dr M Baker, Access to Higher Education: Participation, Equity and Policy (Canberra: Commonwealth Tertiary Education Commission, 1986), at 166, 170.

Pearce Report, supra note 1, at 480-481.

Efficiency and Effectiveness Report, supra note 75, at paras 3.79-3.81.

See, eg, Power et al, supra note 77, at 20,45 and 174; and Efficiency and Effectiveness Report, supra note 75, at W.

Figures from CTEC.

Power et al., supra note 77, at 104-113, I72 and 178. "This study was of entry (and failure to gain entry) into higher education in South Australia in 1985, and found that law, with medicine, architecture and fine arts, stood out "as the courses which are the most elitist in terms of students' family background" (at 100). More than half of law students attended independent secondary schools and had fathers who were professionals. The average income of law students' parents was significantly higher than in any other course, and a far greater proportion of law students (27\%) came from families in the top income bracket (more than $\$ 50,000$ per annum) (at 144 , Table 73 ). See also Efficiency and Effectiveness Report, supra note 75, at 73-74.

Power et al, supra note 77, at 212, Table 10.

Pearce Report, supra note 1, at 473.

LHT West, T Hore, EG Eaton \& BM Kermond, The Impact of Higher Education on Mature Age Students (CTEC, 1986) 20.

Pearce Report, supra note 1, at 482.

Goldring, supra note 61, at 1516.

G Williams, Numbers Up + Funding Down $=$ Quality Threatened, Sydney 
Morning Herald, Feb 12, 1991. 1991 at 3.

94

102 Again in 1988 dollars. See W Jamrozik, What's the price of an education?, Sydney Morning Herald, May 7, 1988 at 1.

103 Pearce Report, supra note 1, at 55-56.

104 Transcript of ABC Radio’s “Education Issues” program, June 4, 1987.

105 DEET, “Relative Funding Model: A Draft Proposal” (1990), as discussed in the Australian Financial Review, July 10, 1990.

106 See M Chesterman and D Weisbrot, Legal Scholarship in Australia (1987) 50 Modern Law Review 709-25.

107 Statement of 24 June 1990, included as Annexure B in D Flint, "Financing Law Schools,” paper delivered at the Law Council of Australia's Legal Education Conference, Bond University, Feb 15, 1991.

108 The fee is $\$ 6600$ per semester. Unlike most of the public universities, it is possible to study for three semesters per calendar year at Bond.

109 Flint, op cit. See also L Briggs, Fee-based legal studies urged, The Australian, Feb 20, 1991, at 13.

110 Study of the Labour Market for Academics (1991) (the “Blandy Report”).

111 Id, Executive Summary.

112 Id.

113 W West, Easy entry for foreign academics, The Australian, Mar 13, 1991, at 21.

114 M Lombard and J Zappala, Academic Arthritis? An Examination of Educational Salary Level Relativities in Australia 1970-1990 (Australian Centre for Industrial Relations Working Paper, 1990). See also W West, Academic unions demand big rises, The Australian, June 20, 1990, at 17; C Dawson, Plummeting salaries may make our uni's uncompetitive, The Australian, Sept 19, 1990, at 18; P Totaro, Uni's facing serious brain drain, says survey, Sydney Morning Herald, Sept 19, 1990, at 5; C Johnson, University pay can't compete, says study, Sydney Morning Herald, Sept 21, 1990 at 3; P Totaro, Our academic. the lowest paid, Sydney Morning Herald, Jan 1, 1991 at 5 .

115 Under the union proposals, a lecturer would receive a maximum of $\$ 47,500$; a senior lecturer \$56,500; an Associate Professor $\$ 65,000$ and a Professor $\$ 76,000$.

116 I am indebted to my colleague Phi1 Burgess for these calculations.

117 The Australian position is similar to that in Britain. American law professors at the elite schools generally earn more than appellate court judges, however. See P Atiyah and RS Summers, Form and Substance in Anglo-American Law 
(Oxford: Clarendon Press; New York: Oxford University Press 1987) at 347.

118 For example, the current salary scales of the Legal Officers (Grades 1-3) and Senior Legal Officers (Grades 4-6) in the NSW Public Service tend to be at least 10 per cent higher than equivalent lecturing positions. The salaries of lawyers with Senior Executive Service (SES) contracts far exceed those of associate professors and professors. Working hours and conditions in the public service are also more attractive, and promotion tends to come more readily for public service lawyers than for academic lawyers.

119 Pearce Report, supra note 1, at para 15.92.

120 F Gibb, Law schools facing crisis as underpaid lecturers leave jobs, The Times, Oct 11,1990 at 4.

121 Sydney Morning Herald, Dec 30, 1988 at 8, and Feb 11, 1989 at 1. 